\title{
Effect of Environmental Fairness on Assets Utilization in the Nigerian Oil and Gas Companies: An Empirical Analysis
}

\author{
Olubunmi Ogunode*, Folajimi Adegbie \\ Department of Accounting, Faculty of Management Sciences, Babcock University, Ilishan-Remo, Nigeria \\ Email address: \\ adexybum@yahoo.com (O. Ogunode), adegbief@babcock.edu.ng (F. Adegbie) \\ ${ }^{*}$ Corresponding author
}

To cite this article:

Olubunmi Ogunode, Folajimi Adegbie. Effect of Environmental Fairness on Assets Utilization in the Nigerian Oil and Gas Companies: An Empirical Analysis. Journal of Finance and Accounting. Vol. 8, No. 5, 2020, pp. 230-237. doi: 10.11648/j.jfa.20200805.14

Received: September 9, 2020; Accepted: September 21, 2020; Published: September 28, 2020

\begin{abstract}
Protection of environment and evidence of such efforts by companies sensitive to the environmental issues have not been convincingly clear. The attitudinal landscape of insensitivity and unfair treatment of environmental protection by the environment sensitive establishments in the downstream activities have become worrisome, particularly where expected returns from assets utilization now overrides concern the planet protection and fair treatments of the host communities where they operate. Consequently, an examination of environmental fairness and its effects on assets utilization. The population consisted of 12 oil and gas companies engaged in the downstream activities. Selection of companies using a purposive sampling technique for a period of 16 years 2003-2018 was explored. Inferential statistics was adopted in the data analysis and multicollinearity test carried out to determine the presence or absence of multicollinearity, showed no negative effect, while Breusch-Pagan / Cook-Weisberg test for heteroscedasticity was carried out for residual constantans. Environmental fairness had a statistically and positively significant impact on asset utilization $\left(\right.$ Adj $^{2}=0.30$; F-statistics $(3,44)=226.3$; $p$-value $=0.00<$ 0.05). The study recommended that management of oil and gas companies should also ensure adequate support to the community through corporate social responsibility by implementing policies that reflect their environmental consciousness as well as ensuring full disclosure of all such activities in their published annual reports.
\end{abstract}

Keywords: Assets Utilization, Downstream Activities, Environmental Fairness, Oil Spillage, Pollutions

\section{Introduction}

In today's world, the issues of environmental fairness driven largely by the business activities of oil and gas companies are causing further global concern. For example, according to Heade [23] in research done at the Climate Accountability Institute, United States, the top 20 oil and gas companies are responsible for at least $35 \%$ of the world's carbon dioxide and methane emissions. According to the report, these emissions have totaled 480 billion tonnes of carbon dioxide equivalent since 1965 , and as it is there is little evidence of this slowing down. This, therefore, has serious implications for environmental balance and climate change. Apart from defective environmental disclosures, two other key elements of environmental fairness also affect the operational efficiency of companies. These include decommissioning costs and corporate social responsibility (CSR). The International Atomic Energy Agency, [24] stated that this has, therefore, become a major problem in that while companies strive to reduce their costs and hence improve their operational efficiency, they are faced with the challenge of doing this without unduly creating environmental imbalances and this impending environmental fairness. Resource consumption, production, distribution, and inventory management are all common aspects of operational efficiency [15]. Efficiency is not only reducing cost or increasing profits but also involves maintaining quality, providing services while retaining customers. Operational efficiency is a critical element for business excellence and is clearly demonstrated when a company systematically manages its resources such that output is maximized.

Sirisha [48] opined that not only will operational 
inefficiency impede profitability, but also the ability of companies to remain adequately capitalized for their future operations. This position is further reinforced by Alemayetu and Belete [7] who stressed that a company that persistently makes a loss will ultimately erode its capital base and consequently put equity and debt holders at risk, a scenario that no investors will appreciate it.

In the view of Muralidhar [36], a company can attain high operational efficiency if it concentrates on reducing waste and improvement of its business practices. Measuring operational efficiency in an optimum way depends on the industry involved and the quality of data available. For example, in the water industry, Ablanedo-Rosas, Campanur, Olivares-Benitez and Nunez [1] suggest the use of bootstrap data envelopment analysis (DEA) and bootstrap truncated regression analysis methods. Similarly, for waste management, Dias, Madaleno, Robaina and Meireles [11] recommended the use of the collection capacity use (CCU) and the segregated waste collection efficiency (SWE) methods. Irrespective of the method used, the desired end result of operational efficiency is optimum use of limited organizational resources. To survive and prosper, companies must therefore of necessity produce their output from inputs deployed in an efficient manner [44].

The process of crude oil exploration with its attendant environmental consequences has continued to be a major concern to various stakeholders including environmentalists, activists, regulatory agencies, and green investors. These environmental consequences include land degradation, depletion of the ozone layer, air pollution, deforestation, loss of biodiversity, oil spillage and water pollution from effluent discharge. Jike (29) observed that the exploitative tendencies of the oil and gas companies in stealing fossil fuel had truncated the sustainability of the Niger Delta environment in Nigeria.

In consideration of the backdrop, some previous researchers' such as [41, 26, 5, 34] had attempted some studies of the impact of environmental accounting on corporate performance but a careful review showed that none had specifically considered the impact of decommissioning cost alongside CSR on the operational efficiency of oil and gas companies. Also, while a number of previous scholars had concentrated on the link between environmental accounting and other industry segments such as the manufacturing industry [40], there is a dearth of available studies focusing specifically on the oil and gas industry. This is despite the fact that the top 20 oil and gas companies are responsible for at least $35 \%$ of the world's carbon dioxide and methane emissions [23].

Research Objective: Evaluate the effect of environmental fairness on assets utilization of selected oil and gas companies in Nigeria.

Research Question: How does environmental fairness affect the assets utilization of selected oil and gas companies in Nigeria?

Research Hypotheses $\left(\mathrm{H}_{0} 1\right)$ : Environmental fairness has no significant effect on assets utilization of selected oil and gas companies.

\section{Literature Review}

\subsection{Conceptual Review}

\section{Assets Utilization}

Adebayo [3] explained that asset utilization is a ratio that can serve as a warning or yardstick to elicit meaningful conclusions about the operational efficiency of a company. It represents a measure of how a firm is efficiently managing its resources to ensure profitability. An optimal asset utilization ratio implies that the firm is more efficient with each unit of asset held for business purposes. Iormbagah, Nwaorgu and Ihendinihu [27] opined that it measures the difference between what an asset is capable of producing and what the asset actually produces. It is thus seen as a tool for identifying asset opportunity gaps. Thus, this study adopts the definition provided by Iormbagah, Nwaorgu and Ihendinihu [27] which sees assets utilization as the measurement of the difference between what an asset is capable of producing and what it actually produces.

\section{Environmental Fairness}

Environmental fairness (EJ) concerns must be embedded in the pursuit of sustainable development of every area of Nigeria more especially for the oil-producing region of the Niger Delta. According to Dimick [12], the concept of justice in education draws on multiple understandings of equity and equality; it is one of the most ubiquitous and under-theorized concepts in science education[30].

According to Lazear [31], environmental fairness is a widely used concept in academia to depict methods local people use to challenge any identified environmental anomalies meted at them. It could arguably be said that the concept of corporate social responsibility is an offshoot of environmental fairness. In the words of Leone and Rock [32], a combination of the Environmental fairness and assets combination should produce profitability. According to Miller [35] required that those who would be affected by the impact of environmental decisions have a right and should take part in such decisions and have their opinions and interests genuinely put into consideration; environmental regulations and laws be fairly and duly applied and enforced and the risk associated with the environment be fairly distributed across the society.

\section{Oil Spillage in Nigeria}

According to Nwankwoala and Oborie [38], UNDP [52] carried out a survey and found out that oil spill incidents have occurred in different parts of the coastal areas in times past in which there were records between 1976 and 2001 that indicated 6,817 oil spills that occurred in Nigeria and resulted in the loss of approximately three million $(3,000,000)$ barrels of oil. This represents an average of 273 oil spills and 115,000 barrels per year that spilled during the period mentioned earlier. According to the Department for Petroleum Resources (DPR), a total of 4,647 incidents resulted in an oil spill of approximately 2,369,470 barrels 
between 1976 and 1996. Nwilo and Badejo, [39] and that out of this quantity, an estimated 1.8 million barrels (about 77\%) were lost to the environment.

Abosede, [2] investigated that Mobil Idaho's blows in January 1999 resulted in spilling of 40,000 barrels of oil. Aghalino and Eyinla [4] stated that Shell reported it spilled 7,350 barrels of oil between 1989 and 1994 and a total of 221 spills occurred in the course of its operation. It is however not unlikely that these figures are under-reported. According to Nigeria's National Oil Spills Detection and Response Agency (NOSDRA), approximately 2,400 oil spills were reported between 2006 and 2010 that resulted from sabotage, bunkering, and poor infrastructure). Galadima, Garba, Leke, AlMustapha and Adam, [20] carried out a study and found out that the available data indicate that approximately $6 \%$, $25 \%$, and $69 \%$ respectively of total oil spills were in the land, swamp and offshore environment.

Corporate Social Responsibility

Umoren, Ogbari and Atolagbe [51], some significant and common features of corporate social responsibility for oil and gas industry include: Price fluctuation [46]; increasing pressure on managers by shareholders focusing on value creation instead of output because of low returns on investments [45] from Malaysia; Complexity of drilling and production process [22] from Singapore; Increasing demand for oil and gas in most regions (BP, 10); health and safety exercise (HSE) compliance remaining critical -especially in the current environment of volatile prices and cost savings; protection of the social license of operation from Pakistan and corporate social responsibilities; Fluctuation of fiscal regimes; research and development (R\&D) and innovation; Handling growing size of data and knowledge management; and unstable partnership of national oil companies and International Oil Companies - NOC-IOC [54]. The challenges mentioned above are a set of effective factors that have hit major oil and gas producing companies in the process of implementing sustainable development policies. In this context, Uwuigbe et al., [53] opined that the spotlight is turning to focus on the role of business in society and companies are seeking to distinguish themselves through engagement in what is referred to as CSR.

\section{Environmental Disclosure}

Environmental disclosures refer to the mandatory or voluntary reporting of information by organizations as it relates to their environmental activities. Corporate social disclosures remains an important area of stakeholder management, as it shapes external perceptions of the firm, helps stakeholders significantly in assessing whether the firm is a good corporate citizen, and eventually justifies the firm's continued existence to its stakeholders [42].

Similarly, Brammer, Brooks and Pavelin [9] stated that environmental disclosures are used as a tool for influencing perception and actions of stakeholders. According to Sengottuvel [47], studies investigating why companies disclose environmental information in their annual or environmental reports have found that the reasons for disclosures relate to demands by corporate stakeholders, environmental groups, regulations, and improving corporate productivity and competitiveness. Simple adherence to mandatory environmental reporting is insufficient to meet the environmental disclosure expectation of stakeholders. Mandatory reporting is nothing but a minimum prescribed reporting requirement. Companies must adopt sustainability reporting standards that are measured up to global best practices.

\subsection{Theoretical Review}

\section{The Triple Bottom Line Theory}

The triple bottom line theory of corporate social responsibility dictates that corporate leaders should tabulate results not only in economic terms but also in terms of company effects in the social realm and with respect to the environment Elkington, [15]. Wiedmann and Lenzen [55] submit that the objective of TBL accounting is, in addition to the growth of shareholder value, the attainment of social and environmental goals, and that TBL accounting is primarily concerned with quantitative, financially-expressed indicators, rather than qualitative, non-monetary economic, social and environmental ones, since according to them, for decision makers only information expressed in financial terms represents the development of sustainable performance. In other words, it is a financial language for decision-makers which can be used to ensure the success of efforts to achieve corporate sustainability. Zerban [56].

Jackson, Boswell and Davis, [18] submit that since TBL involves additional reporting, businesses will need to incorporate additional information in the reports provided to better communicate with stakeholders. The triple bottom line (TBL) thus consists of three Ps: profit, people, and the planet. It aims to measure the financial, social, and environmental performance of the corporation over a period of time. Only a company that produces a TBL is taking account of the full cost involved in doing business [13].

\subsection{Empirical Review}

Bassey, Effiok and Eton [8] examined the impact of environmental accounting and reporting on organizational performance with particular reference to oil and gas companies operating in the Niger Delta Region of Nigeria. The study was conducted using Pearson's product-moment correlation coefficient in which the elements were selected by means of random and stratified sampling technique and it $\mathrm{t}$ was discovered from the study that environmental cost has a significant relationship with the firm's profitability. It was however concluded that environmentally friendly companies will significantly disclose environmentally related information in financial statements and reports. The study recommended that the company should adopt a uniform method of reporting and endeavor to disclose environmental issues for the purpose of control and measurement of performance. Also, accounting standards should be published locally and internationally and reviewed continually to ensure dynamism and compliance to meet environmental and 
situational needs.

In their own study on the impact of environmental accounting and reporting on organizational performance, Bassey, Effiok and Eton [8] revealed that environmental accounting and reporting enhances the organizational performance of the selected oil and gas companies and those environmentally friendly organizations who voluntarily disclose their environmental activities enjoy a high level of competitiveness. For example, money spent on the purchase of pollution control devices on smokestacks will increase GDP, even though the expenditure is not economically productive (Enahoro, 16). Also, certain environmental goods are not marketed even though they provide economic value.

Esira, Ikechukwu, and Ikechukwu, [17] examined the effect of 'Environmental Cost Management on the profitability of the Oil Sector in Nigeria' and found out that the land degradation problem has gone global and has worsened the situation of environmental cost on the productivity of the Nigerian oil sector. Therefore, the study aimed at ascertaining the effects of environmental cost management on the profitability of oil sector in Nigeria and obtained data from the Central Bank of Nigeria (CBN). The result revealed that there is a significant relationship between the influence of environmental cost management and the profitability of the oil sector in Nigeria. Also, it was discovered that there are established standards in Nigeria guiding environmental cost management in the oil and gas industries in Nigeria.

It was also discovered that there are established standards in Nigeria guiding environmental cost management in the oil and gas industries but there is a gap in external reporting of environmental cost data in Nigeria. It was therefore concluded that the extent of environmental cost management in the oil sector is at its developing stage. It was however recommended there should be consistent Policy put in place to improve external reporting in environmental cost data and that United Nations Environmental Cost Management Accounting (ECMA) guideline should be adopted to enhance the effectiveness of the already adopted Internationally Financial Reporting Standards (IFRS) in Nigeria which evolves environmental cost management accounting practice that should be encouraged. In summary, therefore, it could be observed that a significant number of previous studies considered the use of costs tracking systems and the extent of environmental disclosures to measure corporate performance. However, these are considered not sufficient especially given the voluntary nature of environmental disclosures and the absence of strict enforcement of standardized cost tracking system.

\section{Research Methodology}

The research design adopted for this study is ex-post facto. The study population consisted of 12 oil and gas companies engaged in the downstream activities. Data for the study were sourced from the selected companies using a purposive sampling technique for a period of 16 years 2003-2018.
Inferential statistics was adopted in the data analysis and multicollinearity test carried out to determine the presence or absence of multicollinearity, revealed no figure, while the Breusch-Pagan / Cook-Weisberg test for heteroscedasticity was carried out to determine if the variance of the residual is constant.

\section{Operationalization of Variables}

$$
\mathrm{Y}=f(\mathrm{X})
$$

$$
\begin{aligned}
& \mathrm{Y}=\text { Dependent Variables }=\text { Assets Utilization: AU } \\
& \mathrm{Y}=\mathrm{y}_{1} \\
& \mathrm{X}=\text { Independent Variables=Environmental Fairness: EF } \\
& \mathrm{X}=\mathrm{x}_{1}, \mathrm{x}_{2}, \mathrm{x}_{3} \\
& \text { Where: } \\
& \mathrm{y}_{1}=\text { Assets Utilization }=\mathrm{AU} \\
& \mathrm{x}_{1}=\text { Corporate Social Responsibility }=\mathrm{CSR} \\
& \mathrm{x}_{2}=\text { Decommissioning Cost }=\mathrm{DC} \\
& \mathrm{x}_{3}=\text { Environmental Disclosure }=\mathrm{ED} \\
& \text { Model Specification }
\end{aligned}
$$

$$
\begin{gathered}
\mathrm{Y}_{\mathrm{it}}=\beta_{0}+\beta_{1 \mathrm{it}}+\beta_{2 \mathrm{it}}+\beta_{3 \mathrm{it}}+\varepsilon_{\text {it }} \\
\mathrm{AU}=\mathrm{f}(\mathrm{CSR}, \mathrm{DC}, \mathrm{ED}) \\
\mathrm{AU}_{\mathrm{it}}=\beta_{0}+\beta_{1} \mathrm{CSR}_{\mathrm{it}}+\beta_{2} \mathrm{DC}_{\mathrm{it}}+\beta_{3} \mathrm{ED}_{\mathrm{it}}+\varepsilon_{\mathrm{it}}
\end{gathered}
$$

Where:

$\mathrm{AU}_{i t}=$ Assets Utilization in year ${ }_{t}$ for firms ${ }_{i}$

$\beta_{0=}$ the intercepts

$\beta_{1-3}=$ the coefficients

${ }_{i}=$ cross-sectional variable

${ }_{t}=$ time series variable

$\varepsilon=$ the error terms

\section{Results and Discussion of Findings}

\subsection{Descriptive Statistics}

Table 1. Descriptive Statistics Result.

\begin{tabular}{llllll}
\hline Variable & Obs & Mean & Std. Dev & Min & Max \\
\hline AU & 48 & 5.608 & 2.957 & 1.786 & 13.834 \\
CSR & 48 & 17.048 & 0.543 & 15.057 & 17.736 \\
ED & 48 & 4.195 & 0.909 & 1.571 & 5 \\
DC & 48 & 6.741 & 1.089 & 4.377 & 8.338 \\
\hline
\end{tabular}

Source: Researcher's Computation, 2020

From the reported statistics in Table 1 Asset Utilization (AU) also reported a mean value of 5.608 and a standard deviation of 2.957. This confirms the low volatility as the difference between the minimum and maximum values are 1.786 and 13.834. From the reported descriptive statistics, Corporate Social Responsibility (CSR) shows a range between 15.057 and 17.736. This indicates that there is a narrow gap between the minimum and maximum values of environmental fairness. The standard deviation of 0.543 is too large compared to the mean value of 17.048 and this suggests that there is a slim dispersion from the mean and the variable which implies a low unpredictability. 


\subsection{Inferential Statistics}

Table 2. Regression Analysis - Effects of Environmental Fairness on Assets Utilization.

\begin{tabular}{lllll}
\hline Variables & Coefficient & Std. Error & t-stat. & Probability \\
\hline CSR & 0.11 & 0.31 & 0.12 & 0.90 \\
ED & 0.77 & 1.07 & 7.33 & 0.00 \\
DC & 0.06 & 0.01 & 0.17 & 0.86 \\
CONS & 3.04 & 3.26 & 10.38 & 0.00 \\
F-stat & 226.31 & & & \\
Prob (F-stat) & 0.00 & & & \\
Adjusted R & 0.50 & & & \\
\hline
\end{tabular}

Source: Author's Computation (2019): $\mathrm{p}<0.05$

Source: Researcher's Study, 2020

$$
\begin{gathered}
\mathrm{AU}_{\mathrm{it}}=\beta_{0}+\beta_{1} \mathrm{CSR}_{\mathrm{it}}+\beta_{2} \mathrm{DC}_{\mathrm{it}}+\beta_{3} \mathrm{ED}_{\mathrm{it}}+\varepsilon_{\mathrm{it}} \\
\mathrm{AU}_{\mathrm{it}}=3.04+0.11 \mathrm{CSR}_{\mathrm{it}}+0.77 \mathrm{DC}_{\mathrm{it}}+0.06 \mathrm{ED}_{\mathrm{it}}+\mathrm{e}_{\mathrm{it}}
\end{gathered}
$$

From table 2, $\left(A U_{i t}=3.04+0.11 C S R_{i t}+0.77 D C_{i t}\right.$ $\left.+0.06 E D_{i t}+\mathrm{e}_{\mathrm{it}}\right)$ the regression result showed that all the proxies of environmental fairness $(\mathrm{EJ})$ that is $\mathrm{CSR}=0.11$, $\mathrm{ED}=0.77$ and $\mathrm{DC}=0.06$ have positive effect on Asset Utilization (AU). This indicates that a unit increase in CSR will bring about 0.11 increases in $\mathrm{AU}$; a unit increase in ED will cause a 0.77 increase in $\mathrm{AU}$; a unit change in $\mathrm{DC}$ will cause a 0.06 increase in AU. The statistical significance of each proxy revealed that CSR has a significant impact on AU $(p=0.00<0.05)$; ED showed a significant impact on $\mathrm{AU}$ $(p=0.00<0.05)$; DC showed an insignificant impact on AU $(p=0.24>0.05)$. With the $F$-statistics of 226.3 and the $p$-value of 0.0 which is less than 0.05 level of significance adopted, we rejected the null hypothesis and accepted the alternate, which means that the entire model is significant. The Adjusted $\mathrm{R}^{2}$ of 0.30 explains that only $30 \%$ of the total variation is explained by the independent variables, while the balance of $70 \%$ is explained by variables outside the study.

Furthermore, the effect of environmental fairness as investigated revealed that some findings were consistent with prior studies. The regression analysis shown in Table 2 revealed that Environmental fairness (EJ) has a positive and significant impact on Asset Utilization. This finding is supported by Asoquo [6] who concluded in his study that the related cost of environmental protection and management positively influences a firm's profitability (AU). The finding is further supported by that of Iqbal, Subrisno, Prihat, and Rosidi [26] with the conclusion that environmental accounting implementation and environmental information disclosure are able to give an effect on company value. Lastly, Bassey, Effiok and Eton [8] and Esira, Ikechukwu and Ikechukwu [17] also concluded that there is a significant relationship between the influence of environmental cost management and the profitability (AU) of the oil sector in Nigeria.

\section{Implication of Findings}

Following the findings, this study can be beneficial to future researchers, corporate bodies, top executives of oil and gas companies, regulatory agencies, environmental experts and the government.

Specifically, the following would find this study useful:

Investors and Shareholders: The findings of the study would be useful to both prospective investors and existing shareholders when setting investment portfolio priorities especially in the face of global uncertainties or volatilities in the oil industry. Furthermore, the study will assist in providing the needed assurance to shareholders that expenditures incurred in being environmentally acceptable will not negatively impact on their investments and hence the valuation of the companies.

Management of Oil and Gas Companies: The management especially, the top management-level could derive major policy implication from the results of this study especially given that it has established that there is a nexus between investments in CSR activities and be operationally efficient. As the companies improve their efficiency levels, shareholders value is enhanced and opportunities for better returns in terms of compensations and benefits will also, come the way of such top management personnel.

Regulators and Policy Makers: Regulators, the Department of Petroleum Resources (DPR) and Financial Reporting Council of Nigeria (FRCN), would find the outcome of this study useful especially in formulating accounting and financial guidelines that will help reduce information asymmetry and foster compliance with policy requirements, for example, proper treatment of decommissioning costs. Also, the study could help guide against tax evasion and likely illegal transfer pricings activities by multinational oil and gas companies if full disclosure and transparency in financial reporting is maintained. This will translate to greater investment in the Nigerian capital market and consequently increase shareholders' wealth.

Academia: This study could as well be useful to scholars and academia in the field of accounting who are interested in examining the increasing demand expectations of various stakeholders in the oil and gas industry especially as it relates to meeting Financial Reporting requirements.

Analysts and NGOs: The analysts and activists that work tirelessly to champion the cause for a better society and reduction in environmental degradation will also find this study useful. This study, having established the positive relationship that exists between environmental fairness proxies such as adherence to good CSR practices and transparent environmental disclosures, on one hand, operational efficiency, on the other hand, will enable NGOs demand greater accountability from oil and gas companies.

Accounting Profession/Practice: This study extends the frontiers of emerging academic literature in the Accounting profession especially considering the twin concepts of Environmental fairness and Assets Utilization.

\section{Conclusion and Recommendations}

Conclusions: Findings provide insight into the effects of environmental fairness on the operational efficiency of listed 
oil and gas companies in Nigeria. It further provided insight, effects of environmental fairness on variables of assets utilization variables of operational efficiency. It also provides an affirmation the variations in the dependent variables are caused by environmental fairness covered in the models as depicted by the adjusted R-squared.

Recommendations: The study recommends that there is the need for regulatory authorities through the local content agency of the government to ensure that oil and gas companies at all times, incur appropriate amounts with regard to decommissioning cost since it is the company's responsibility. This is to protect the communities from their hazardous effects when the asset runs out of its useful life. The management of oil and gas companies should also ensure adequate support to the community through corporate social responsibility. This it can do by urgently implementing policies that reflect their environmental consciousness as well as ensuring full disclosure of all such activities in their published annual reports.

\section{References}

[1] Ablanedo-Rosas, J. H., Campanur, A. G., Olivares-Benitez E., Nunez-Rios J. E., (2020). Operational efficiency of Mexican utilities: Results of a double-bootstrap data envelopment analysis. International Journal of Urban Water Management, $12(2) 52-53$

[2] Abosede, O. O. (2020) Oil pollution and water conflicts in the riverine communities in Nigeria's Niger Delta region: challenges for and elements of problem-solving strategies, Journal of Contemporary African Studies, DOI: $10.1080 / 02589001.2020 .1730310$

[3] Adebayo, O. A (2013). Understanding Statistics, (2 ${ }^{\text {nd }}$ Ed). Lagos; JAS Publishers.

[4] Aghalino, S. O., \& Eyinla, B. E. (2009). Oil exploitation and marine pollution: evidence from the Niger Delta, Nigeria. Journal of human ecology (Delhi, India), 28 (3), 177-182 DOI: 10.1080/09709274.2009.11906236

[5] Adediran, S. A., Alade, S. O. (2013). The impact of environmental accounting on corporate performance in Nigeria. European Journal of Business and Management, 5 (23), 141-151.

[6] Asuquo, A, I. (2012). Environmental friendly policies and their financial effects on corporate performance of selected oil and gas companies in Niger delta region of Nigeria. American International Journal of Contemporary Research, 2 (1), 168173.

[7] Alemayetu A., Belete A. K., (2019). Assessing the effect of operational efficiency on the performance of private and state owned commercial banks in Ethiopia. Open Journal of Economics and Commerce. 2 (4), 18-27.

[8] Bassey, E. B., Effiok, S. O., \& Eton, O. E. (2013). The impact of environmental accounting and reporting on organizational performance of selected oil and gas companies in Niger delta region of Nigeria. Research Journal of Finance and Accounting, 4 (1), 57-73.

[9] Brammer, S., Brooks, C., \& Pavelin, S. (2006). Corporate
Social Performance and Stock Returns: UK Evidence from Disaggregate Measures. Financial Management, 35 (3).

[10] BP. (2017). Energy outlook 2017. Retrieved from http://www.bp.com/content/dam/bp/pdf/energyeconomics/energy-outlook-2017/bp-energy-outlook-2017.pdf. Retrieved 12/12/2018.

[11] Dias, M. F., Madaleno, M., Robaina, M., \& Meireles, M (2019). Eco-innovation, innovation and firm performance: are proactive environmental firms more profitable? Sustainability Research, 2 (1), 1-8.

[12] Dimick, A. S. (2012). Student empowerment in an environmental science classroom: Toward a framework for social justice science education. Journal of Science Education, 96 (5), 990-1012.

[13] Dierkes, M. (2013). Corporate social reporting in Germany: conceptual development and Practical experience.

[14] Elkington, J. (1997). Cannibals with Forks: The TBL of the 21 st century Business. Oxford, Capstone.

[15] Elkington, J. (2004). Enter the triple bottom line. The triple bottom line: Does it all add up, Journal of Economic, 1 (1), 116 .

[16] Enahoro, J. A. (2009). Environmental Accounting for sustainable environmental values and virtues. Journal of Accountancy, and Management Companion, 2 (2), 1-13.

[17] Esira, A. F., \& Ikechukwu, E. C., \& Ikechukwu, E. M. (2014). Environmental cost management and profitability of oil sector in Nigeria (2004-2013). Journal of Good Governance and Sustainable Development in Africa (JGGSDA), 2 (2), 181-192.

[18] Epstein, M. J. (2011). Measuring corporate environmental performance; Institute of Management accountants Journal, 2 (1), $1-9$.

[19] Fleming, G., Heaney, R., \& McCosker, R. (2005). Agency costs and ownership structure in Australia. Pacific-Basin Finance Journal, 13 (1), 29-52.

[20] Galadima, A., Garba, Z. N., Leke, L., Almustapha, M. N., Adam, I. K. (2011). Domestic water pollution among local communities in Nigeria: Causes and consequences. European Journal of Scientific Research, 52 (4), 592-603.

[21] Gray, R., Kouhy, R., \& Lavers, S. (2010). Corporate social and environmental reporting, a review of the literature and a longitudinal study of UK. Disclosures. Accounting Auditing and Accountability Journal, 8 (2), 47-77.

[22] Gupta, V., \& Grossmann, I. E. (2017). Offshore oilfield development planning under uncertainty and fiscal considerations. Optimization and Engineering, 18 (1), 3-33.

[23] Heade, R. (2019). Carbon Majors: Accounting for carbon and methane emissions. Methods and Results Report. The Climate Accountability Institute, United States.

[24] International Atomic Energy Agency (1997). Joint convention on the safety of spent fuel management and on the safety of radioactive waste management, IAEA INFCIR/546, IAEA, Vienna (1997).

[25] Iskandar, M. T., \& Bukit, R. B., Sanusi, Z. M., (2012). The moderating effect of ownership structure on the relationship between free cash flow and assets utilization. Asian Academy of Management Journal of Accounting and Finance. 8 (1) 69-89. 
[26] Iqbal, M., Subrisno, T., Prihat, R., \& Rosidi. (2013). Effect of environmental accounting implementation and environmental performance and environmental information disclosure as mediation on company value. International Journal of Business and Management Invention, 2 (10), 55-67.

[27] Iormbagah, J. A. Nwaorgu, I. A., \& Ihendinihu, J. U. (2019). Effect of corporate tax on sustainable financial performance of listed firms in Nigeria. Journal of Social Sciences, 12 (7), 231245 .

[28] Jackson, A., Boswell, K., \& Davis, D. (2011). Sustainability and triple bottom line reporting-What is it all about. Int. J. Bus. Humanities Technology, Retrieved from http://www.ijbhtnet.com/journals/Vol_1_No_3_November_20 11/6.pdf

[29] Jike, V. T. (2004). Environmental degradation, social disequilibrium, and the dilemma of sustainable development in the Niger-Delta of Nigeria. Journal of Black Studies, 34 (5), 686-701.

[30] Kayumova, S., McGuire, C. J., \& Cardello, S. (2018). From empowerment to response-ability: rethinking socio-spatial, environmental justice, and nature-culture binaries in the context of STEM education. Cultural Studies of Science Education, 14 (4) 205-229.

[31] Lazear, E. P. (2014). Performance pay and productivity. American Economic Review, 90 (6), 1346-1361.

[32] Leone, A. J., \& Rock. S. (2002). Empirical tests of budget ratcheting and its effect on managers' discretionary accrual choices. Journal of Accounting and Economics, 33 (1), 43-67.

[33] Liker, J. K. (2004). The Toyota way: 14 management principles from the world's greatest manufacturer (2nd edition). New York: McGraw-Hill.

[34] Makori, D. M., \& Jagongo, A. (2013). Environmental accounting and firm profitability: an empirical analysis of selected firms listed in Bombay Stock Exchange, India. International Journal of Humanities and Social Science, 3 (18), 248-256.

[35] Miller, G. T. (2011). Environmental science: Working with the earth (9th edition). Pacific Grove, California: Brooks/Cole.

[36] Muraldhar P., (2018). Analysis on improving operational efficiency of construction project site. Independent Journal of Management and Production. 9 (3), 20-24.

[37] Nagle, G. (2012), business Environmental Cost Accounting survey. In Global Environmental management initiative 2012 conference processing's March 16-17.

[38] Nwankwoala, H. O., \& Oborie, E. (2018). Geological and hydrogeological characterization of a hydrocarbon impacted site in the Niger Delta. Pakistan Journal of Geology, 2 (1), 1217. DOI: $10.26480 /$ pjg.01.2018.12.17

[39] Nwilo, P. C., \& Badejo, O. T. (2005). Oil spill problems and management in the Niger Delta. International Oil Spill Conference Proceedings: 1 (1), 567-570. https://doi.org/10.7901/2169-3358-2005-1-567

[40] Odewole, O., (2018). Environmental accounting and stakeholders' value of listed manufacturing companies in Nigeria. Unpublished PhD Dissertation, Babcock University, Ilishan Remo, Nigeria.
[41] Okafor, C., \& Oshodin, E. (2012). Corporate social responsibility and corporate performance in Nigeria. Journal of Management and Corporate Governance, 4 (1), 24-31.

[42] Okwanga, B. C., Mungania A. K., Karanja J. G., (2015). Analysis of factors affecting the operational efficiency of Jua Kali Sector: a case study of apparel industry in Nairobi, Kenya. European Journal of Business and Management, 7 (30), 20-25.

[43] Onyali, C. I. (2014). Triple bottom line accounting and sustainable corporate performance. ResearchJournal of Finance and Accounting, 5 (8), 195-209.

[44] Osazefua I. J. (2019) Operational efficiency and financial sustainability of listed manufacturing companies in Nigeria. Journal of Accounting and Taxation. 11 (1), 17-31.

[45] Ramos, S. B., Taamouti, A., Veiga, H., \& Wang, C. W. (2017). Do investors price industry risk? Evidence from the crosssection of the oil industry. Journal of Energy Markets, 5 (2), 11-25.

[46] Regnier, E. (2007). Oil and energy price volatility. Journal of Energy \& Economics, 29 (3), 405-427.

[47] Sengottuvel, C. (2018). Environmental accounting and firms' profitability. International Journal of Innovative Research in Management Studies, 3 (1), 22-27.

[48] Sirisha, S., \& Malyadiri, P. (2018). A study on operational efficiency and financial strength of Indian banking industry. International Journal of Economics and Financial Research, 4 (2), 46-55.

[49] Umukoro, N. (2018). Home grown solution to African problem: harnessing innovation for petroleum refining in Nigeria. Strategic Planning for Energy and the Environment, $37: \quad 4, \quad 58-73, \quad$ DOI: $10.1080 / 10485236.2018 .12002426$

[50] Umukoro D. E., (2018). Decommissioning of offshore Energy installations: what lessons can Nigeria learn from the United Kingdom. Journal of Oil, Gas and Energy Law, 2 (1), 2-5.

[51] Umoren, A., Ogbari, M. E., and Atolagbe, T. M. (2016). Corporate social responsibility and firm performance: A study of listed companies in Nigeria. A paper presented at ICAN 2nd Annual International Academic Conference on Accounting and Finance, at Lagos Airport Hotel, Ikeja on 20th May, 2016.

[52] UNDP. (2006). Human development report 2000: human rights and human development Available at: http:/hdr.undp.org/en/content/human-development-report2000. Retrieved: $12^{\text {th }}$ August 2020.

[53] Uwuigbe, U., Daramola, S. P., \& Oyeniyi, A. (2014). The effects of corporate governance mechanisms on earnings management of listed firms in Nigeria. Accounting and Management Information Systems, 13 (1), 159-174.

[54] Whitson, C. H. (2009). International vs. national oil companies-What's the difference? The way ahead. Journal of Sustainability, 5 (03), 10-11.

[55] Wiedman, T., Lenzen, M., Tuner, K., \& Barret, J. (2006). The impact of ethical tools on aggressiveness in financial reporting. Ecological Economics, 61 (1), 15-26. 
[56] Zerban, A. (2013). The need for social and environmental accounting standards: Can Islamic countries have the lead? Eurasian Journal of Business and Management, 1(2), 33-43. 